\title{
Restructuring and the Nonmetropolitan Turnaround: The California Evidence
}

\author{
BARNEY WARF*
}

\begin{abstract}
Conceptions of nonmetropolitan growth have rarely benefited from current debates in social theory. An analytical interpretation of the literature on the "turnaround" is offered from a structuralist perspective. In this model of industrial restructuring, the routinization of the labor process via capital intensification is seen to engender the dispersal of firms to outlying areas through the internalization of linkages. Empirical evidence from California confirms this notion, as population growth is tied to labor markets in which capital-intensive production forms are extensive. Economic base analysis indicates the rapid growth of the service sector is relatively less significant in such areas.
\end{abstract}

ONTEMPORARY GROWTH trends in the United States exhibit an unprecedented resurgence of small, often undistinguished urban places-the nonmetropolitan "turnaround" (Beale 1972, 1975; Fuguitt 1972, Long 1981, Morrison and Wheeler 1976, Tucker 1976). Decentralization of both demographic and economic phenomena has become the focus of a considerable body of geographic literature (Berry 1976, Bourne 1980, Morrill 1980). Unfortunately many studies of the turnaround have sacrificed the construction of a satisfactory theoretical framework for an essentially empiricist outlook: the social processes which assume the geographical form of nonmetropolitan growth have often been treated superficially.

This paper offers an analysis of the relations between nonmetropolitan employment and population growth and the recent body of theory that portrays urban growth trends in terms of the

* Dr. Warf is an assistant professor of geography at the University of Connecticut, Storrs, CT 06268. 
"restructuring" of capital-labor relations (Massey and Meegan 1978, Scott 1980). California, the nation's most populous state, provides a useful microcosm in which such theoretical propositions may be tested. Despite the voluminous literature on the turnaround at the national level, very little has been written regarding specifically regional contexts, especially in the rapidly growing West. Accordingly, the purpose of this paper is to document the extent to which the turnaround in California illuminates the industrial restructuring process in general.

\section{The Restructuring of Production}

The recent engagement of geography with the broader domain of social theory has produced, among other things, several structuralist alternatives to neoclassical economic interpretations of industrial urbanization (Massey 1983, Massey and Meegan 1978, Peet 1983, Scott 1980). In contrast to the tendency of much of the literature on nonmetropolitan growth to view the turnaround as an essentially demographic or sociophysiological phenomenon (e.g. Carpenter 1977, Fuguitt and Zuiches 1975, Tregarthen 1977), this perspective takes the production system, i.e., the spatial division of labor, to be the central point of departure in the investigation of capitalist society. In somewhat abbreviated terms, it holds that the organization of urban areas is structured and continually restructured by the locational demands of firms, which are mediated territorially through an integrated system of inputs and outputs. The compelling forces of market competition insistently require firms to streamline the production process by reducing their aggregate labor costs and increasing net capital investments. Associated changes, e.g., changes in demand, may be held to comprise secondary moments which reflect, rather than determine, the primary nature of the production process. With these comments in mind, it is possible to delimit the locational requirements of firms largely through their capital and labor inputs.

Firms that use relatively high proportions of labor also frequently exhibit most, if not all, of the following characteristics: vertically disintegrated forms of production, short production runs that change rapidly and irregularly, and frequent design changes, 
all of which combine to make investments in fixed capital costly because of the expenses incurred in changing set-up specifications and the constant modifications in production design (Scott 1982a). Further, they tend to evince significant levels of subcontracting, large varieties of inputs and outputs, and high per unit transport costs (which do not reflect the economies of scale available to firms that haul large quantities). Such forms of production, which typified many nineteenth-century production complexes, generally are dominated by small producers locked into fierce competition with one another.

These types of linkages impose severe locational constraints which induce such firms to cluster together in the core areas of large cities, where they may take advantage of agglomeration economies and maximize their accessibility to the urban labor pool. Faced with copious quantities of inputs and outputs, the transport costminimizing strategies induce these labor-intensive forms of production, in typical Weberian fashion, to create densely occupied areas of high rents. Hence, inasmuch as certain industrial systems use relatively large amounts of labor and exhibit vertically disintegrated forms of production, they tend to form concentrated urban centers typified by high interfirm linkages (Scott 1982b). It may be argued further that these remarks characterize not only most early industrial cities, but also typify the core area of many contemporary metropolitan areas, which have witnessed a clustering of skilled white collar and administrative labor (e.g., large law firms, banks and insurance headquarters).

As the incessant process of captial deepening proceeds, driven by competitive pressures to lower costs, production becomes increasingly standardized, and unit transport and production costs decline as firms integrate their forward and backward linkages. In so doing, they internalize the economies of scale that formerly existed as external "urbanization economies" by increasing the length of production runs within larger plants. Design changes throughout this process either halt or become markedly less frequent, and contacts with buyers and sellers both "up and down stream" assume more regular and predictable forms. As the labor process becomes progressively routinized, there is a lesser need for expensive skilled 
labor, inducing a net deskilling of workers through the fragmentation of jobs, the substitution of craft labor by less skilled workers, and the embodiment of skills in machinery (Braverman 1974).

Capital deepening also gradually relaxes the locational requirements prevalent among specialized, labor-intensive firms and the service sector, many of which require frequent interaction and "face-to-face" contact. It follows that firms in suburban and nonmetropolitan locations possess relatively dispersed linkage systems in which material costs figure significantly. The decline of per-unit input and output costs thus allows large, relatively capital-intensive firms to enjoy a greater locational freedom through the presence of economies of scale in transport costs. In the restructuring framework, then, industrial movements are hypothesized to be the result of the attraction of low-wage, capital-intensive firms to areas that enjoy a comparative advantage in the production of standardized products, such as the generation of "footloose" branch plants that are evident in much of the southern and western parts of the United States today.

With the onset of these changes, the comparative advantage of centralized locations declines notably. As their reliance upon central city labor pools and agglomeration economies falls, replaced by economies of scale in production and transportation, industrial plants are encouraged to flee their formerly profitable centralized locations, freed from the high rents and frequently unionized labor pools characteristic of the increasingly uncompetitive core areas. Concomitantly, greater labor productivity reduces the aggregate demand for labor, exacerbating a tendency towards "technological displacement" in the central areas of older cities. While such movements have made suburban income levels significantly higher than central city ones (Moffitt 1977), the increased wages of a smaller labor force may be incurrred more easily by capital-intensive firms than by labor-intensive ones.

In short, the process of capital intensification presents itself through a series of social and spatial moments: the formation of labor-intensive complexes, subsequent movements away from core areas, i.e., decentralization and the subsequent disintegration of large urban complexes, and, finally, the formation of dispersed 
production patterns. For core regions, this trend signifies the steady appearance of a long litany of social and financial horrors: waves of plant closures, declining real wages, union breaking, rising unemployment, and fiscally decimated local governments (Bluestone and Harrison 1982, Richardson and Gordon 1979), "rolling up the carpet, as it were" (Walker and Storper 1981). These immediate effects, accentuated through multipliers in local housing and "nonbasic" labor markets, induce serious declines in the quality of life, job prospects, and expectations of future consumption, encouraging a widespread emotional climate of depression and hopelessness in such areas. Conversely, in conformity with the logic of the spatial division of labor articulated here, cities and regions on the periphery of the urban and national space-economy recently have witnessed significant increases in jobs and wages and correspondingly lower levels of poverty.

When viewed in these terms, the formation and dissolution of large production complexes definitively resolves the annoying question as to whether or not the turnaround represents a "temporary reversal" or a continuation of long-term trends of urban growth. Further, the restructuring process manifests itself at several spatial scales-at the intraurban, interurban, or even international levels-so that the persistent growth of metropolitan peripheries, nonmetropolitan areas, the Sunbelt, and the recent waves of corporate flight to Third World nations may be viewed as one overarching process rooted in the fundamental architectonics of commodity production. The restructuring framework provides, therefore, significant conceptual advantages over the rather eclectic explanations commonly found in the literature.

The restructuring model differs substantially from the two dominant theories of industrial dispersal generally employed to explain nonmetropolitan economic growth-the "filtering" or product cycle model and the "post-industrialization" framework. The oft-invoked product cycle model holds that industrial decentralization results from changes in production accompanying the evolution of commodities through their life cycles (Cromley and Leinbach 1981, Erickson 1976, Norton and Rees 1979, Park and Wheeler 1983). After "incubating" in large urban "seedbeds," firms change 
their locational requirements as they enter a standardization phase that favors low-cost peripheral areas (Rees 1979). Decentralization, or filtering, results:

In national perspective, industries filter down through the system of
cities, from places of greater to less sophistication. Most often, the
highest skills are needed in the difficult, early stage of mastering a new
process, and skill requirements decline steadily as the production
process is rationalized and routinized with experience. As the industry
slides down the leaning curve, the high wage rates of the more industri-
ally sophisticated innovating areas become superfluous. The aging
industry seeks out industrial backwaters where the cheaper labor is
now up to the lesser demands of the simplified process. [Thompson 1973, p. 8]

Within the urban system "it is, of course, small towns and rural areas that constitute the lowest rung of the filtering process" (Hansen 1975). Although product cycle theory captures the essential form of industrial dispersal, its explanation of the underlying dynamics remains insufficient, for it tends to gloss over the fact that commodity production is a social as well as a technical process. Technology, for example, tends to be portrayed as an autonomous, disembodied force devoid of social roots. Scott (1982a, p. 8) argues that it

is a theory that appears not to go far enough or deeply enough into the dynamics of the production system and their spatial consequences. . . . It is evident that the relative locational shift of industry from the core of the large metropolis to the periphery and beyond is not so much generated by a product cycle as it is by the historical transformation of the labor process involving the deepening and restructuring of capital under the pressure to accumulate. These transformations may occur whether or not there is a product cycle in the strict sense of a (theoretically privileged) evolution in the form and design specifications of final outputs.

Hence, product cycle theory tends to describe the mechanisms of nonmetropolitan growth in largely metaphorical terms.

A somewhat different school of thought holds that the turnaround represents a new phase in the integration of rural and urban areas, a dispersed state characteristic of the long-heralded "postindustrial" epoch (Berry 1976, Hage 1979, Schwarzweller 1979, Warner 1974). As the service sector is considered to be the core of the post-industrial economy, the turnaround is theorized to result from the dispersion of tertiary activities (Hirsch 1977, Sundquist 1975, Wardwell 1977). It must be realized, however, that although services have grown rapidly in some nonmetropolitan counties, 
they have grown even more quickly in metropolitan ones, replacing manufacturing as the principal form of employment in large conurbations (Emerson and Lamphear 1975, Roepke and Freudenberg 1981, Slaughter 1980). On a more theoretical level, the precise reason as to why services are inherently different from manufacturing remains unclear; both, after all, represent the spatial embodiment of the process that unites labor and capital (although in widely varying proportions). By succumbing to artificial divisions between the office location and industrial location literature, the "post-industrial" theory diverts attention from the pressing task of conceptualizing the space-economy as an integrated totality.

At this juncture the empirical characteristics of the new firms and workers in nonmetropolitan areas are of interest with regard to the viability of these alternative explanations. The socioeconomic status typical of turnaround migrants is not entirely clear, but several studies have indicated that these migrants are disproportionately composed of older, poorly educated, blue-collar workers (Frey 1979, Lichter et al. 1979, Morrison and Wheeler 1976, Wardwell 1977, Zelinsky 1977). Analyses of the firms that attract such persons to nonmetropolitan areas exhibit mixed evidence regarding their capital intensity, yet a significant body of literature has asserted that the electronics, metals, chemicals, machinery, and textiles companies that increasingly dominate the labor markets of small towns throughout the nation (Aydalot 1981, Fitzsimmons et al. 1980, Hamer 1973, Long and DeAre 1983, Slaughter 1980), especially in the South (Briggs and Rungeling 1980, Fisher 1979a, 1979b, Klimasewski 1978, Kuehn and Bender 1975, Till 1974), are low-wage, capital-intensive firms. As the restructuring theory applies also to the service sector, its conclusions are substantiated further by observations that the relatively labor-intensive, whitecollar sector has not decentralized as quickly as has manufacturing (Beyers 1979, Emerson and Lamphear 1975, Hansen 1973, Roepke and Freudenberg 1981, Slaughter 1980), a conclusion which runs directly in opposition to the post-industrialization thesis. In light of this expedition through the nonmetropolitan growth literature, an empirical investigation of the restructuring process in California is offered here. 


\section{The California Growth Reversal}

What has been the extent and nature of the turnaround in California? To what degree is it related to the structural changes in employment? These questions may be addressed in the context of the state's recent trends in metropolitan and nonmetropolitan growth. California's population is extremely clustered, primarily in the metropolitan lowlands of Los Angeles and the San Francisco Bay area. With 92 percent of its population residing in Standard Metropolitan Statistical Areas (SMSAs), California is the nation's most urbanized state. Nonmetropolitan counties, inhabited by 1.9 million of the state's 24 million people, exhibit a wide variety of small communities: agricultural hamlets, wealthy cities in the desert, coastal retirement centers, "countercultural" villages, logging camps, and university towns.

Historically, the great bulk of California's urban growth has been metropolitan. During the century preceding 1950, the state's population exploded 64-fold, the most rapid growth of any industrialized area in the world (Bradshaw and Blakely 1979). Unlike most states, the majority of the population increase was a result of inmigration (mostly to large urban areas), not natural growth (Gordon 1954, Morrison 1971, Vance 1972). The Great Depression of the 1930s induced the first "back-to-the-land" movement in the state (Webster 1937). More recent changes are part of the overall growth of the Sunbelt and the rapid suburbanization that occurred in the 1950s and 1960s. Table 1 illustrates the relatively healthy growth of both metropolitan and nonmetropolitan counties. Unlike

Table 1. California metropolitan and nonmetropolitan population growth (1920-1980)

\begin{tabular}{cccccccc}
\hline \hline & \multicolumn{3}{c}{ Population (millions) } & & \multicolumn{3}{c}{ Percentage growth } \\
\cline { 2 - 4 } \cline { 7 - 8 } Year $^{1}$ & Metro & Nonmetro & California & & Metro & Nonmetro & California \\
\hline 1920 & 2.7 & 0.7 & 3.4 & & ---- & ---- & ---- \\
1930 & 4.8 & 0.8 & 5.6 & & 77.7 & 14.3 & 64.7 \\
1940 & 5.8 & 0.9 & 6.7 & & 20.8 & 12.5 & 19.6 \\
1950 & 9.5 & 1.3 & 10.6 & & 60.3 & 44.4 & 58.2 \\
1960 & 14.2 & 1.4 & 15.6 & & 52.3 & 7.7 & 47.2 \\
1970 & 18.5 & 1.5 & 20.0 & & 30.3 & 7.1 & 28.2 \\
1980 & 21.7 & 1.9 & 23.6 & & 17.3 & 26.7 & 18.0 \\
\hline
\end{tabular}

'SMSAs as defined at the beginning of each decade.

Sources: Bureau of the Census 1970, Forstall 1981. 
the turnaround in the Northeast, nonmetropolitan growth in California (and the West in general) is not one of absolute metropolitan decline and nonmetropolitan gain, but rather of relatively more rapid nonmetropolitan growth.

Roughly one-half million persons, about 2 percent of California's population, moved to the state's 33 nonmetropolitan counties in the 1970s (Bradshaw and Blakely 1979). For the first time since the nineteenth-century Gold Rush, the northern fifty counties of California gained at a faster rate than did the southern eight (Dembart 1981, Sokolow 1977). However, because nonmetropolitan counties comprise a small proportion of the state's population, their relatively high growth rates are overshadowed by the enormous absolute gains of the metropolitan regions (Table 1). For example, the low rate of growth $(5.7 \%)$ of Los Angeles County (the nation's most populous) from 1970 to 1980 included more than 435,000 people, almost equivalent to the total growth in the state's nonmetropoli$\tan$ counties. The principal locus of growth shifted in the 1970s from the large coastal cities to the foothills of the Sierra Nevada, especially to the northern part of the Central Valley (Allen 1977, Sokolow 1977). Figures 1 and 2 show archipelagos of suburban growth around the metropolitan areas and regional subcenters in the Central Valley, indicating the presence of a suburban component to California's turnaround. (Because the West's extensive SMSAs mask the extent of suburbanization, census subcounty units are used here.)

Although California is the nation's largest producer of agricultural and manufactured goods (LaPorte and Bradshaw 1977, Paschall 1977), its economy has differed historically from the nation's by its disproportionately large service sector (Fig. 3). While deconcentration typified local industrial patterns as early as World War II (Parsons 1949), counties with recent high rates of growth in manufacturing jobs have also gained people rapidly (CCSCE 1979; see Fig. 4). Service sector growth has been limited mostly to SMSAs (Fig 5). However, retail trade employment and the movement of retirees, who compromise 25 percent of California's turnaround migrants (Bradshaw and Blakely 1979), also generated growth in many nonmetropolitan areas (Figs. 6 and 7). 

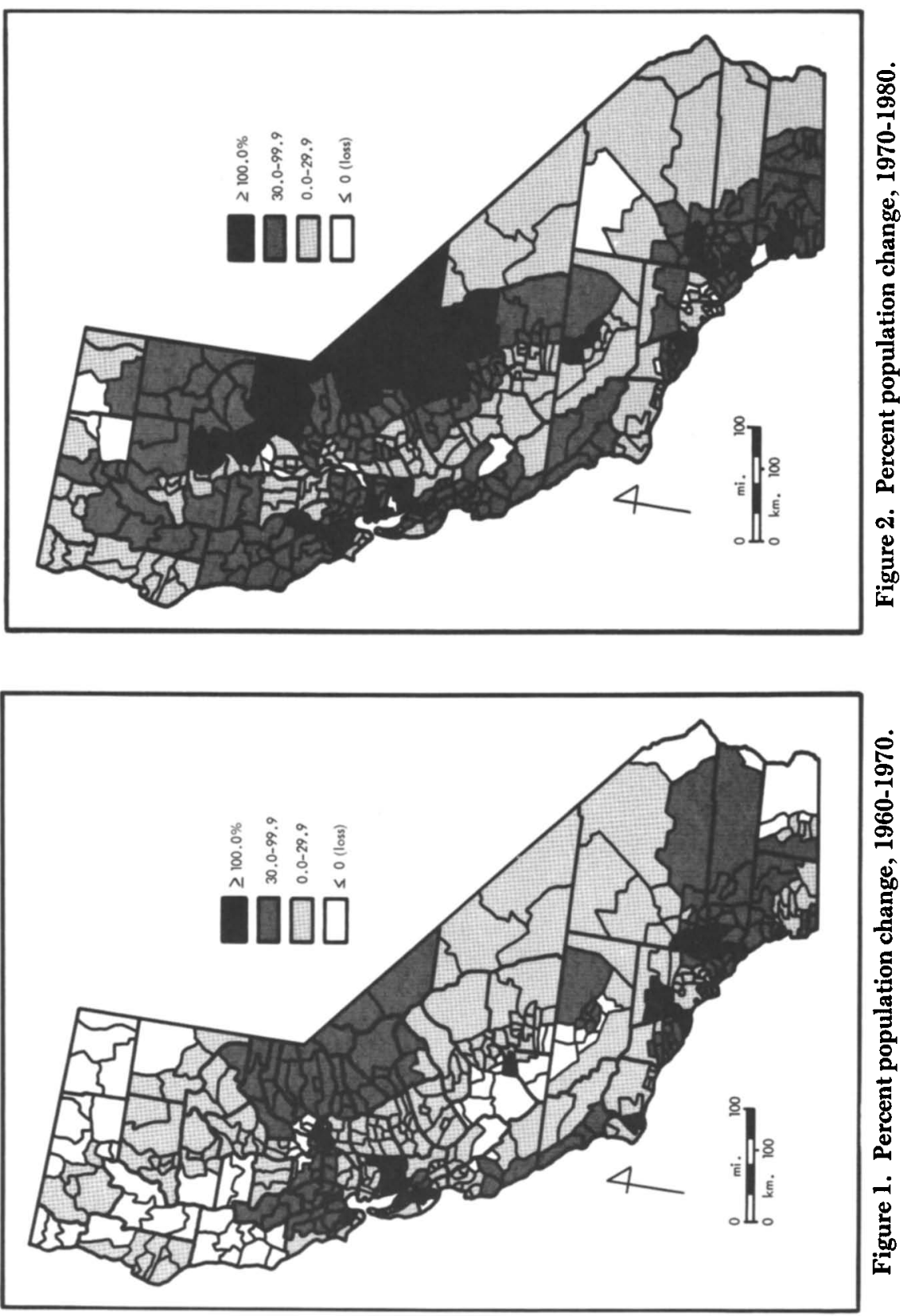


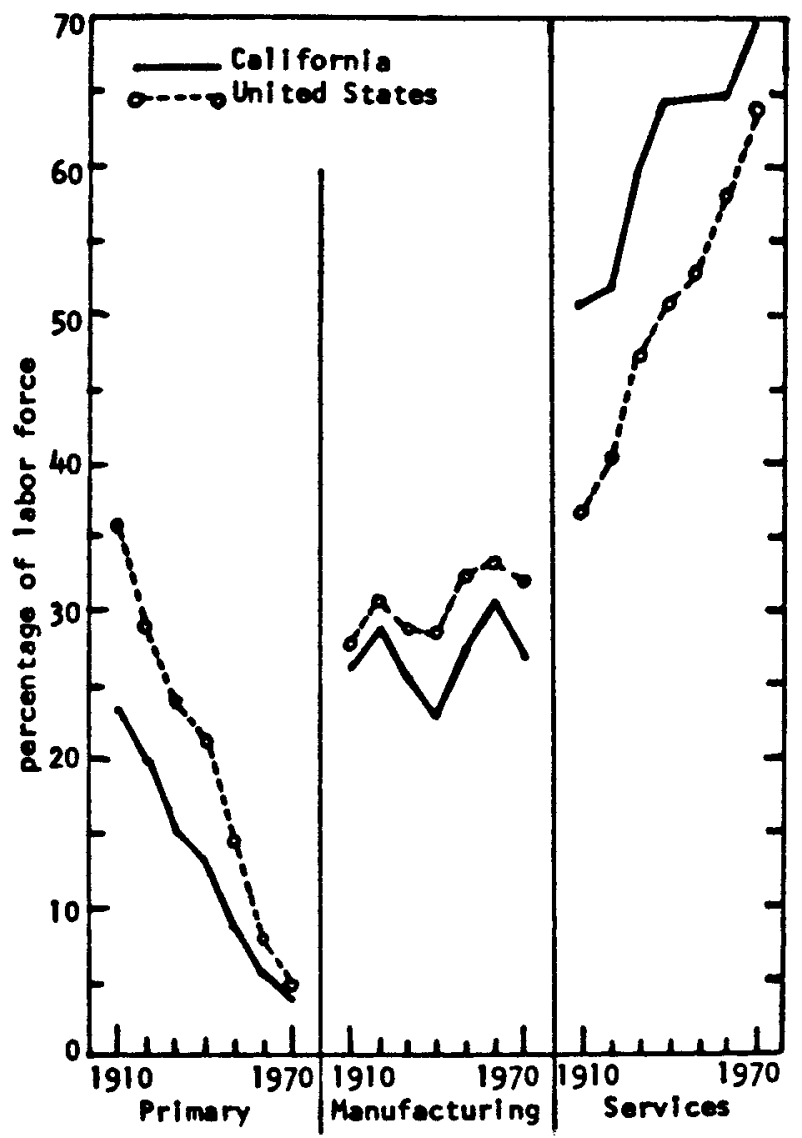

Figure 3. Composition of the California labor force, 1900-1972. (Source: Bradshaw and Blakely 1979.)

Can California's turnaround be attributed to the restructuring process articulated earlier? Central to this theory is the notion that the decentralization of industrial firms, in response to the progressive substitution of capital for labor, has been largely responsible for the dissolution of large urban industrial complexes (and their reconstitution around service sector labor), resulting in the industrial shift to small towns throughout the nation. Accordingly, the hypothesis that population growth should be most rapid in those nonmetropolitan counties that gained in capital-intensive forms of manufacturing is tested here. Relative manufacturing growth in 

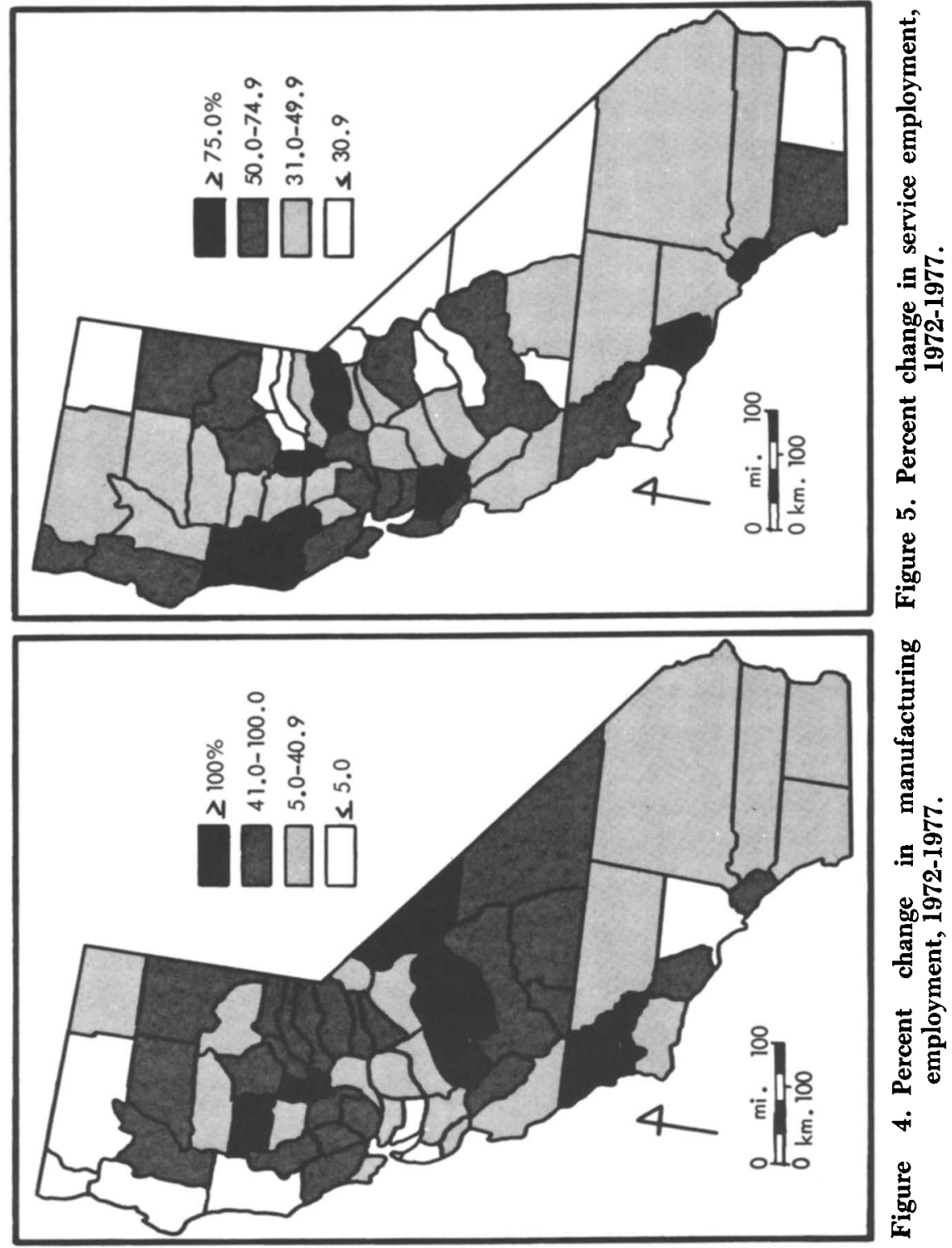

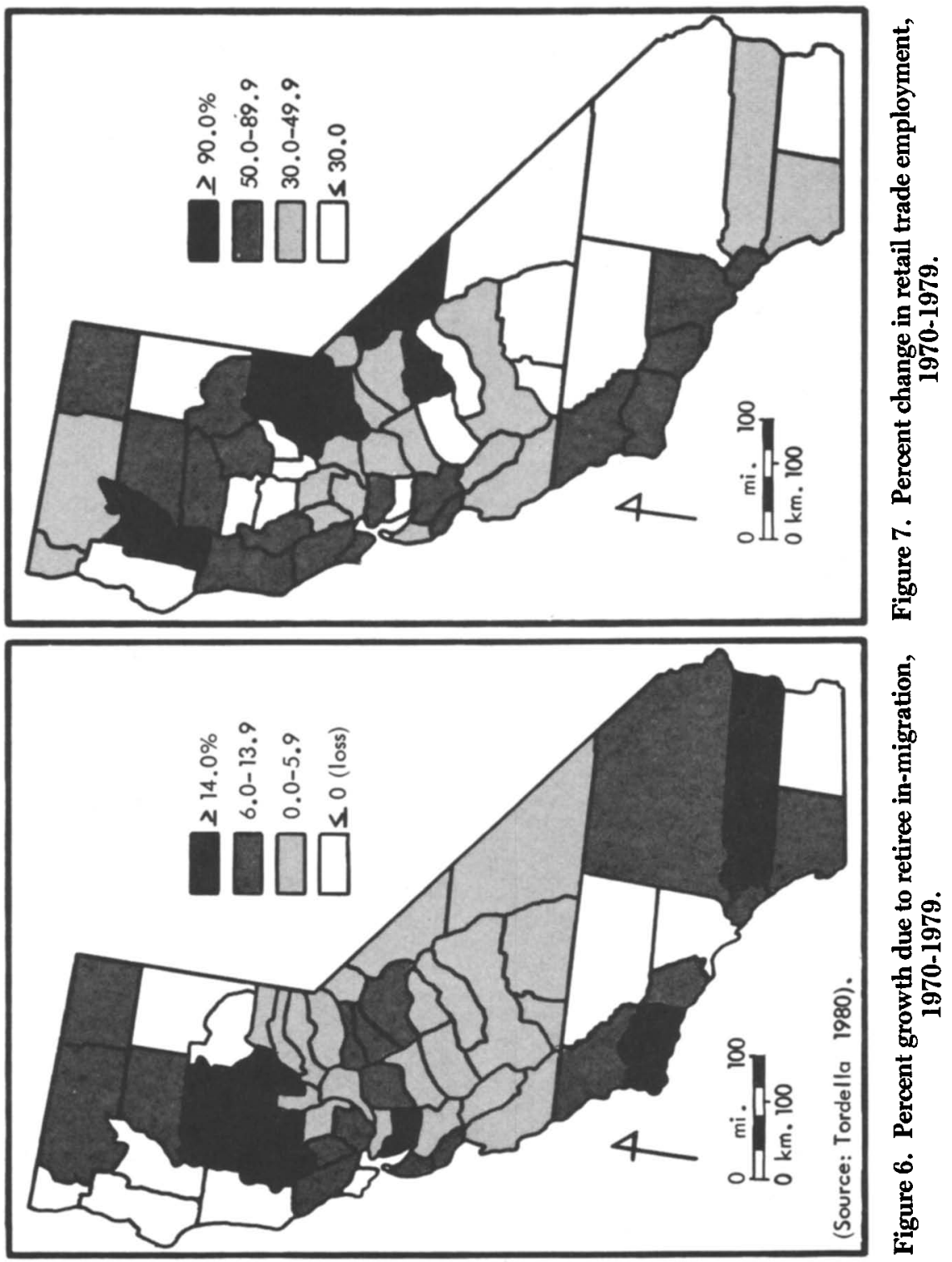
nonmetropolitan California was almost twice that of the SMSAs, especially in nonelectrical machinery, food processing, textiles, and fabricated metals (CCSCE 1979). Many of California's nonmetropolitan labor markets, however, still exhibit a heavy orientation towards food and wood processing. Figure 8 provides additional support for the restructuring hypothesis, as manufacturing growth in nonmetropolitan counties tends to be relatively more capital-intensive when measured by changes in new capital invested and value added by manufacturing.

To measure the relative capital intensity of production over time and among different sectors, the following index was computed:

$$
K_{i j}=\sum_{i}\left(V A_{i j}-W_{i j}\right) / E_{i j}
$$

where $K=$ index of capital intensity (thousands of dollars per employee),

$V A=$ value added (for services, gross receipts were used),

$W=$ wages and salaries,

$E=$ number of production employees,

$i=$ county type (i.e., nonmetropolitan, small or large SMSAs), and

$j=$ economic sector (as defined by two-digit S.I.C. codes).

Essentially this measure estimates the average level of surplus value or net profit per production worker in each sector. Tables 2 and 3 illustrate the status of 18 manufacturing and service sectors in small and large SMSAs and nonmetropolitan counties in 1972 and 1977. While virtually all sectors gained in the amount of surplus value attained per employee, the changes in capital intensity were greatest in nonmetropolitan counties. Further, the strong growth in metropolitan services was accompanied by significant increases in the value of sales per worker. Simple correlations between employment growth and population growth in each sector are shown in Table 4, lending further confirmation to the notion that the turnaround is tied to the growth of capital-intensive firms.

A more detailed analysis of California's service sector was conducted because of its prominence in the regional economy. The relations between service and population growth, however, reveal 

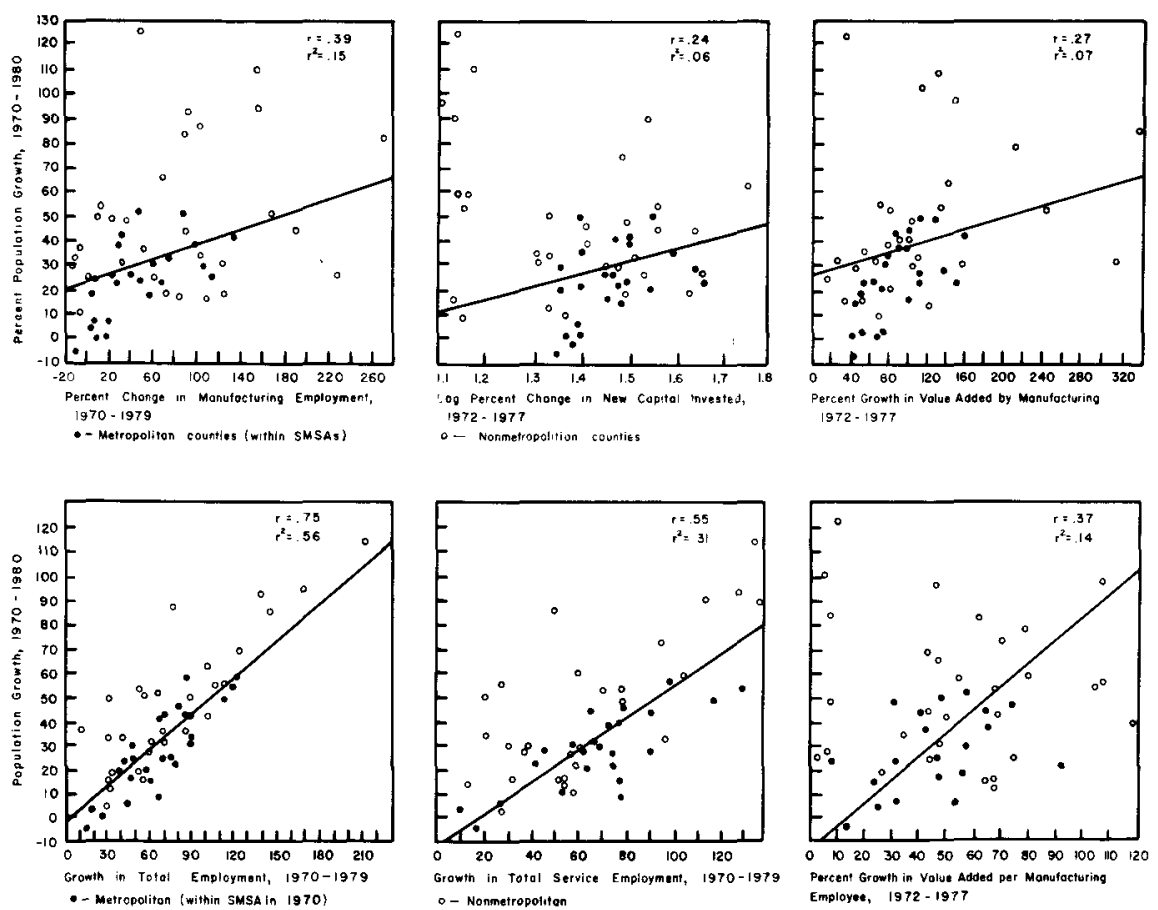

Figure 8. Population growth relative to employment change and capital intensification.

the direction of causality less clearly than do the corresponding trends in manufacturing, for it is conceivable that service sector job growth may occur in large part as a response to population growth as well as being a stimulant of growth, i.e., firms may follow workers. To explore this possibility, economic base analysis was used to estimate the degree to which the growth of service employment was dependent upon local (as opposed to export) market expansion.

In keeping with the standard interpretation, growth in the basic or export-oriented sector was taken to be the foundation of economic and demographic growth. Small "open" economies generally are typified by large basic sectors or low nonbasic employment, while larger, more "self-contained" places have proportionally smaller basic sectors and large nonbasic sectors. The minimum requirements technique was used to estimate basic sector employment for 


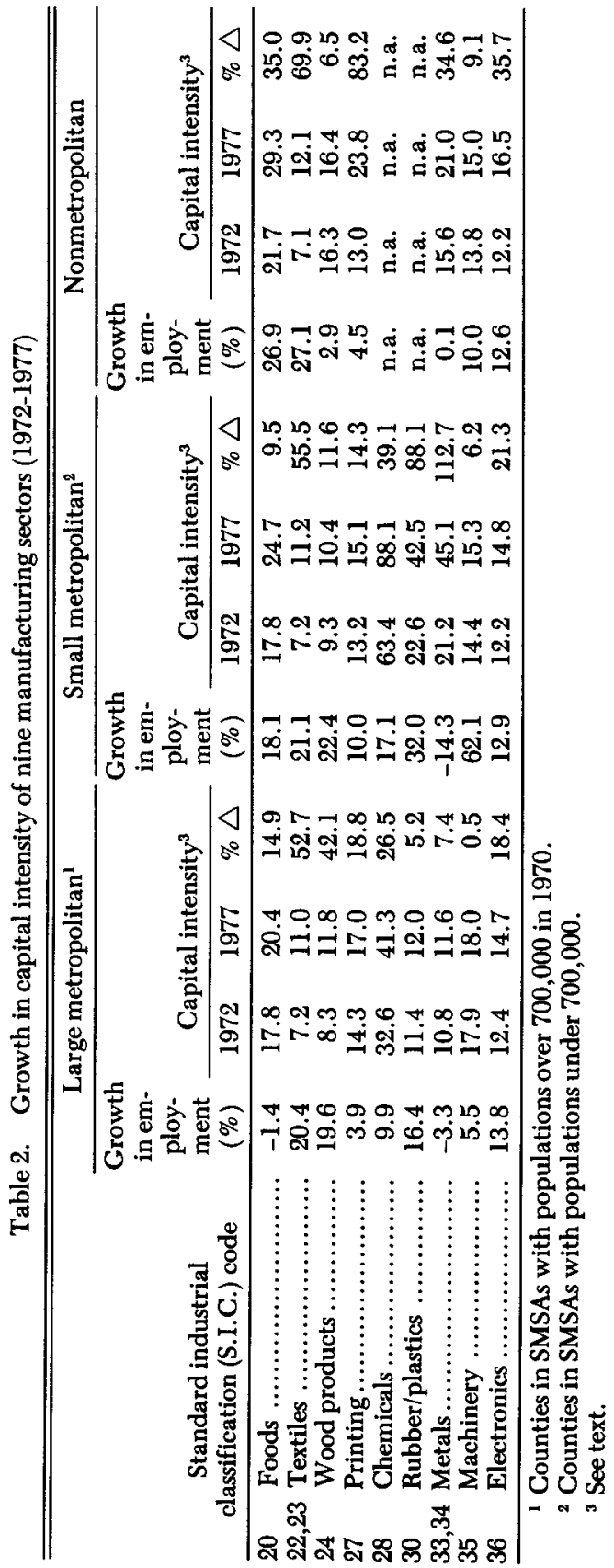




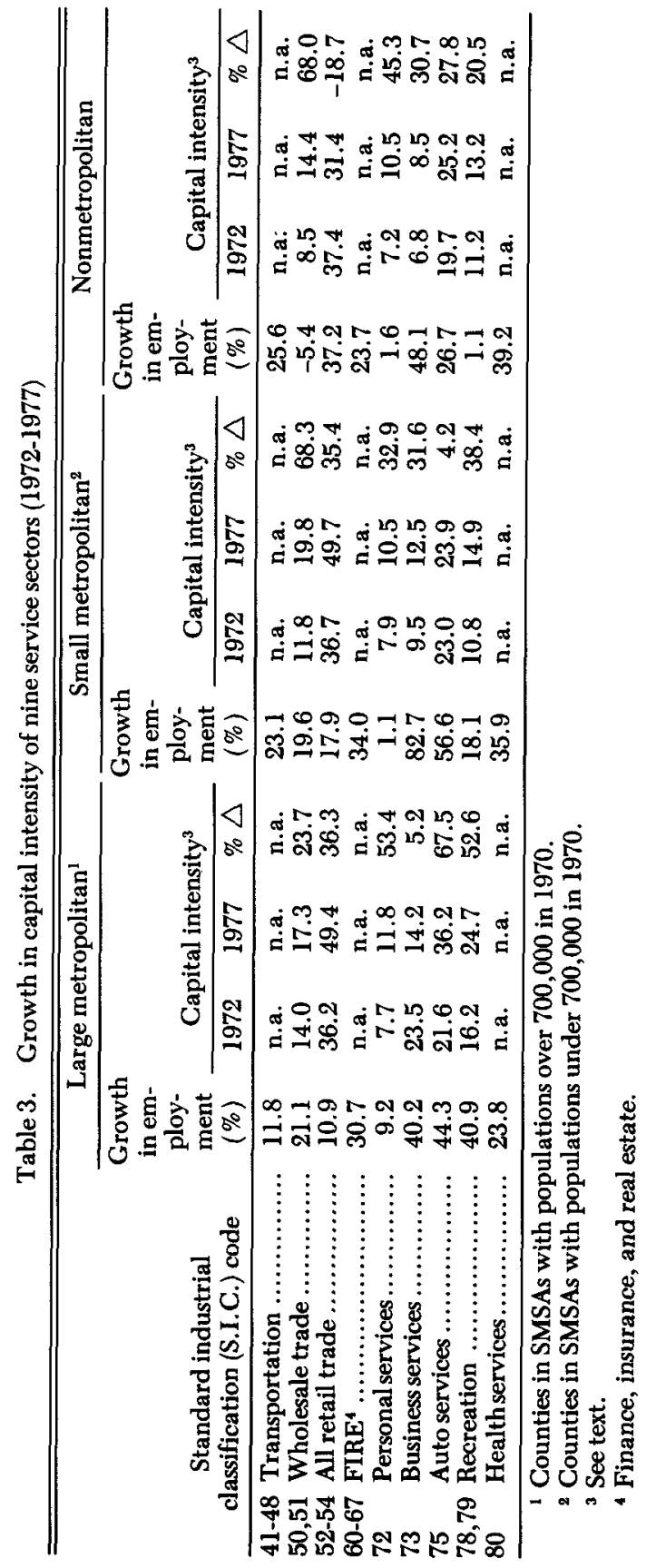


Table 4. Correlations between 1970-1980 population and 1972-1977 employment changes

\begin{tabular}{|c|c|c|c|c|}
\hline $\begin{array}{l}\text { S.I.C. } \\
\text { code }\end{array}$ & $\begin{array}{l}\text { Large metro- } \\
\text { politan }^{1}\end{array}$ & $\begin{array}{l}\text { Small metro- } \\
\text { politan }^{2}\end{array}$ & $\begin{array}{l}\text { Nonmetro- } \\
\text { politan }^{3}\end{array}$ & California $^{4}$ \\
\hline 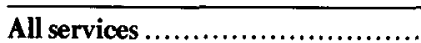 & .54 & .51 & .49 & .52 \\
\hline 41-48 Transportation ............. & .36 & .31 & .28 & .32 \\
\hline 50,51 Wholesale trade .......... & .12 & .14 & -.02 & .10 \\
\hline 52-54 All retail trade ............ & .68 & .69 & .75 & .70 \\
\hline 60-67 FIRE $^{5} \ldots \ldots \ldots \ldots \ldots \ldots \ldots$ & .80 & .72 & .49 & .76 \\
\hline Personal services .......... & .64 & .62 & .58 & .62 \\
\hline Business services ........... & .23 & .32 & .22 & .24 \\
\hline Auto services ................ & .40 & .41 & .44 & .42 \\
\hline 78,79 Recreation ............... & .58 & .59 & .62 & .61 \\
\hline 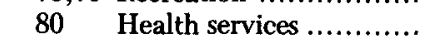 & .77 & .65 & .50 & .68 \\
\hline All manufacturing ................... & .59 & .30 & .38 & .42 \\
\hline Foods & .16 & .29 & .55 & .30 \\
\hline 22,23 Textiles $\ldots \ldots \ldots \ldots \ldots \ldots \ldots$ & .64 & .54 & .44 & .50 \\
\hline Wood products ............ & -.02 & .11 & .47 & .10 \\
\hline Printing ................... & .30 & .19 & .62 & .27 \\
\hline Chemicals ................. & .29 & .29 & n.a. & .29 \\
\hline Rubber/plastics ............ & .09 & .28 & n.a. & .13 \\
\hline 33,34 Metals $\ldots \ldots \ldots \ldots \ldots \ldots \ldots \ldots$ & 19 & .21 & .25 & .21 \\
\hline Machinery ................ & .13 & .17 & .19 & .17 \\
\hline Electronics ............... & .34 & .18 & .08 & .18 \\
\hline Retirement $^{\theta} \ldots \ldots \ldots \ldots \ldots \ldots \ldots \ldots \ldots \ldots \ldots \ldots$ & .18 & .62 & .79 & .57 \\
\hline
\end{tabular}

Italics indicate significance at the .05 fiducial level.

${ }^{1}$ Counties in SMSAs with populations over 700,000 in $1970 ; N=5$.

2 Counties in SMSAs with populations under 700,000 in $1970 ; N=14$.

${ }^{3}$ Not in SMSA in 1970; $N=30$.

${ }^{4} N=49$.

${ }^{5}$ Finance, insurance, and real estate.

${ }^{6}$ Growth in persons over age 65.

different-sized places through the regression of population size on the proportion of nonbasic employment for a sample of fifteen counties. Figure 9 presents minimum requirements estimates of nonbasic employment for ten service sectors for the years 1970 and 1980 . With the exception of retail trade, the proportion of nonbasic employment increased more rapidly in the relatively more populous counties. This means, then, that nonbasic service growth became somewhat more important in SMSAs than in nonmetropolitan counties, precisely in those areas which have either lost population or grown relatively slowly, the "post-industrialization" thesis notwithstanding. In short, the high growth of California's service sector does not appear to be responsible for instigating (although as with retail trade it may accompany) the recent moves to nonmetro- 

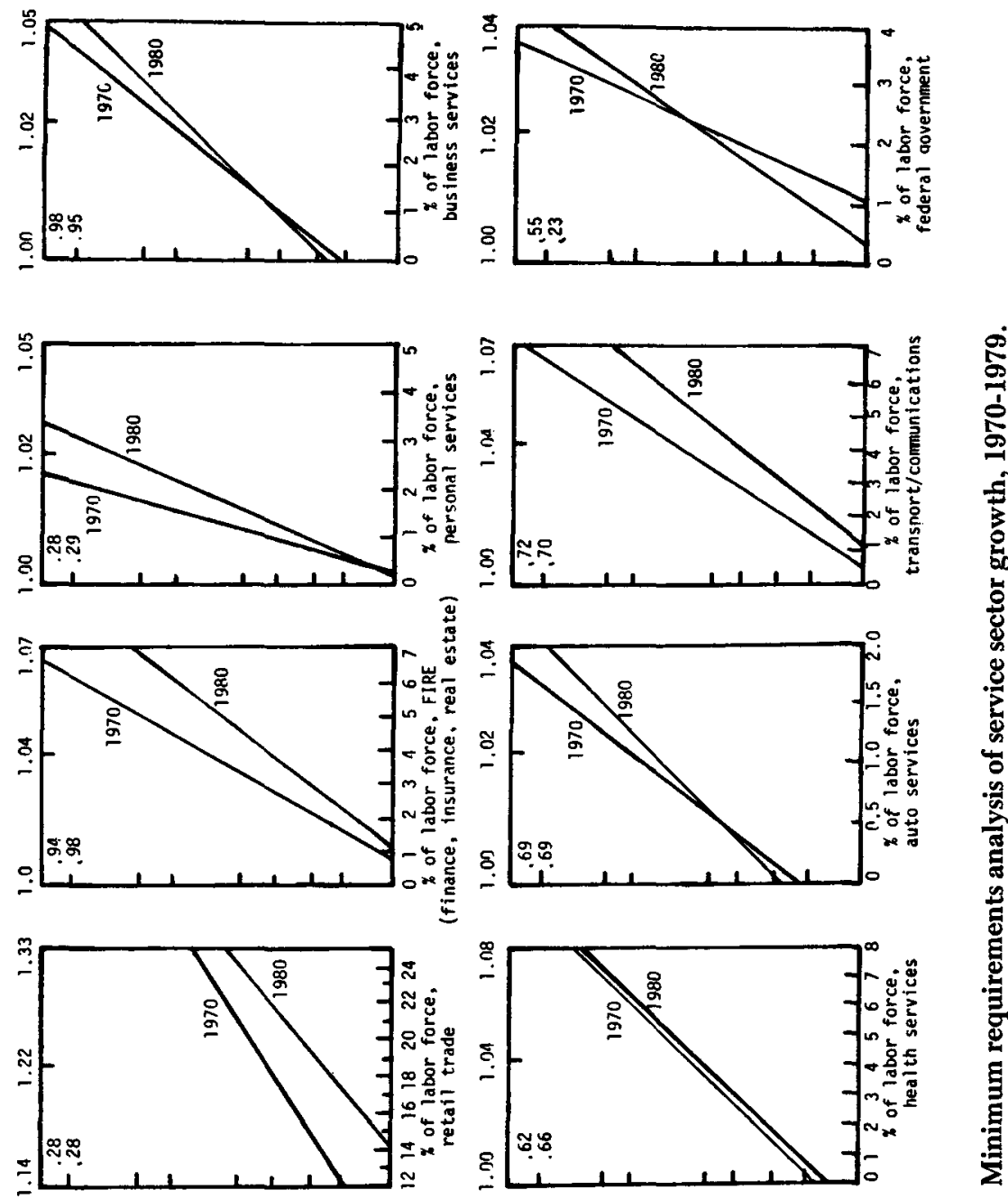

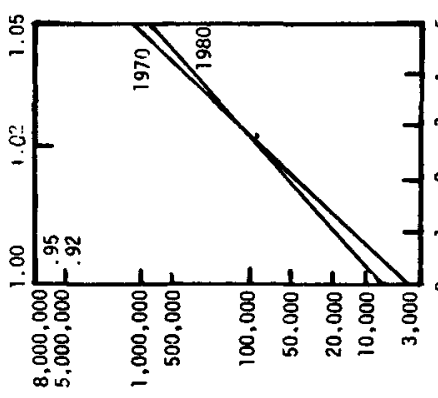

vorzerndod kqunos t*7or
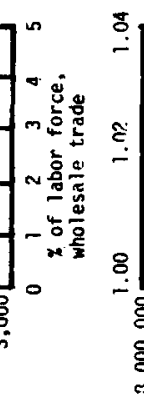

\begin{tabular}{c}
8 \\
8 \\
8 \\
8 \\
\hline
\end{tabular}

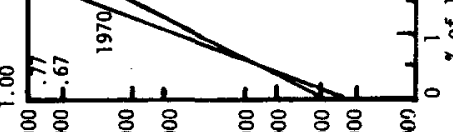

8.

8̊

Uo5zrindod kzunos rozos

定 
politan counties, but it does underpin the transformation of metropolitan areas into complexes of service labor.

Altogether, the results suggest a substantive relationship between nonmetropolitan population growth and industrial employment changes, lending modest but not conclusive confirmation to the restructuring theory. The effects of such capital deepening are evident in the types of nonmetropolitan industrial growth throughout the state and in the increasing mechanization of the agricultural sector (CCSCE 1979). In all likelihood, the growth of California's large service sector has mitigated the detrimental effects of industrial flight from metropolitan conurbations.

\section{Concluding Remarks}

Many analyses of nonmetropolitan growth have paid insufficient attention to the social structures from which spatial configurations derive their form and meaning. This empiricism requires reconsideration in view of the deeply historical nature of spatial phenomena. The literature on the turnaround has largely ignored the structural mainsprings of urban decentralization, particularly the labor process and its relations to urban growth. Thus a reconceptualization of nonmetropolitan growth as the outcome of a historically bound set of production relations is called for, a task undertaken by the literature on the theory of capital and labor restructuring. This analysis suggests that capital deepening has accelerated the flight of industrial firms from centralized locations down the urban system by decreasing manufacturing linkage requirements, lowering transport costs, and heightening the comparative advantage of areas with cheap, unskilled labor pools. Evidence from California lends some confirmation to this model: employment growth in nonmetropolitan areas consistently reflects gains in capital-intensive sectors, while metropolitan growth remains heavily tied to the relatively labor-intensive service sector. Future trends both regionally and nationally likely will reveal a continuation of this pattern, in which the centralization of managerial and administrative jobs in the upper tiers of the urban hierarchy will stand in contrast to the standardized production increasingly characteristic of small cities. 


\section{Literature Cited}

Allen, J. "Patterns of Net In-migration in the Nonmetropolitan West, 1950-75." Great Plains-Rocky Mountain Geographical Journal, 6(1977):108-117.

Ayladot, P. "The Regional Policy and Spatial Strategy of Large Organizations," in Polarized Development and Regional Policy: Tribute to Jacques Boudeville, edited by A. Kuklinski. The Hague: Mouton, 1981.

Beale, C. "Rural and Nonmetropolitan Population Trends of Significance to National Population Policy," in Research Reports, Population Distribution and Policy, edited by S. Mazie. Washington, D.C.: Commission on Population Growth and the American Future, 1972.

Beale, C. The Revival of Population Growth in Nonmetropolitan America. Washington, D.C.: Dept. of Agriculture Research Service Report ERS-605, 1975.

Berry, B. "The Counterurbanization Process: Urban America Since 1970," in Urbanization and Counter-urbanization, edited by B. Berry. London: Sage, 1976.

Beyers, W. "Contemporary Trends in the Regional Economic Development of the United States." The Professional Geographer, 31(1979):34-44.

Bluestone, B., and B. Harrison. The Deindustrialization of America: Plant Closings, Community Abandonment, and the Dismantling of Basic Industry. New York: Basic Books, 1982.

Bourne, L. "Alternative Perspectives on Urban Decline and Population Deconcentration." Urban Geography, 1(1980):39-52.

Bradshaw, T., and E. Blakely. Rural Communities in Advanced Industrial Society: Development and Developers. New York: Praeger, 1979.

Braverman, H. Labor and Monopoly Capital. New York: Monthly Review Press, 1974.

Briggs, V., and B. Rungeling. "Economic Development: A Poverty Solution for the Rural South?" Growth and Change, 11(1980):31-35.

Carpenter, D. "The Potential for Population Dispersal: A Closer Look at Residential Locational Preferences." Rural Sociology, 42(1977):352-370.

CCSCE (Center for Continuing Study of the California Economy). California Growth in the 1980s. Palo Alto, Calif.: California State Publications, 1979.

Cromley, R., and T. Leinbach. "The Pattern and Impact of the Filter Down Process in Nonmetropolitan Kentucky." Economic Geography, 57(1981):208-224.

Dembart, L. "Boom in State's Rural Growth Outpaces Cities." Los Angeles Times, Jan. 18, 1981, p. 1.

Emerson, M., and F. Lamphear. Urban and Regional Economics: Structure and Change. Boston: Allyn and Bacon, 1975.

Erickson, R. "The Filtering-Down Process: Industrial Location in a Nonmetropolitan Area." The Professional Geographer, 28(1976):254-260.

Fisher, J. "Manufacturing Additions in Georgia: Metropolitan-Nonmetropolitan Differences from 1961 to 1975." Growth and Change, vol. 10, pp. 9-16, 1979a.

Fisher, J. "Structural Adjustments in the Southern Manufacturing Sector." The Professional Geographer, vol. 33, pp. 466-474, 1979b.

Fitzsimmons, J., D. Borchert, and J. Adams. "Recent U.S. Population Redistribution: A Geographical Framework for Change in the 1980s." Social Science Quarterly, 61(1980): 485-507.

Forstall, R. "Regional Population Trends in the United States, 1970-1980," paper presented at the annual meeting of the Association of American Geographers, Los Angeles, 1981.

Frey, W. "The Changing Impact of White Migration on the Population Compositions of Origin and Destination Metropolitan Areas." Demography, 16(1979):219-237.

Fuguitt, G. "Population Trends of Nonmetropolitan Cities and Villages in the United States," in Research Reports, Population Distribution and Policy, edited by S. Mazie. Washington, D.C.: Commission of Population Growth and the American Future, 1972. 
Fuguitt, G., and J. Zuiches. "Residential Preferences and Population Distribution." Demography, 12(1975):491-504.

Gordon, M. Employment Expansion and Population Growth: The California Experience: 1900-1950. Berkeley: University of California Press, 1954.

Hage, J. "A Theory of Nonmetropolitan Growth," in Nonmetropolitan Industrial Growth and Community Change, edited by G. Summers and A. Selvik. Lexington, Mass.: Lexington Books, 1979.

Hamer, A. Industrial Exodus from the Central City. Lexington, Mass.: Lexington Books, 1973.

Hansen, N. The Future of Nonmetropolitan America: Studies in the Reversal of Rural and Small Town Population Decline. Lexington, Mass.: Lexington Books, 1973.

Hansen, N. The Challenge of Urban Growth. Lexington, Mass.: Lexington Books, 1975.

Hirsch, W. "The Coming Age of the Polynucleated Metropolis," in Small Cities in Transition: The Dynamics of Growth and Decline. Cambridge: Ballinger, 1977.

Klimasewski, T. "Corporate Dominance of Manufacturing in Appalachia." Geographical Review, 68(1978):94-102.

Kuehn, J., and L. Bender. "A Dissent: Migration, Growth Centers, and the Ozarks." Growth and Change, 6(1975):43-48.

LaPorte, T., with T. Bradshaw. "Advanced Industrial California: Employment Patterns." California Data Brief, 1(1977).

Lichter, D., T. Heaton, and G. Fuguitt. "Trends in the Selectivity of Migration Between Metropolitan and Nonmetropolitan Areas, 1955-1975." Rural Sociology, 44(1979):645-666.

Long, J. "Population Deconcentration in the United States." Bureau of the Census Special Demographic Analysis CDS-81-5, 1981.

Long, L., and D. DeAre. "The Slowing of Urbanization in the U.S." Scientific American, 249(1983):33-41.

Massey, D. "Industrial Restructuring as Class Restructuring: Production, Decentralization and Local Uniqueness." Regional Studies, 17(1983):73-89.

Massey, D., and R. Meegan. "Industrial Restructuring Versus the Cities." Urban Studies, $15(1978): 273-288$.

Moffitt, R. "Metropolitan Decentralization and City-Suburb Wage Differentials." International Regional Science Review, 2(1977):103-111.

Morrill, R. "The Spread of Change in Metropolitan and Nonmetropolitan Growth in the United States, 1940-1976." Urban Geography, 1(1980):118-129.

Morrison, P. "The Role of Migration in California's Growth," in California's Twenty Millions: Research Contributions to Public Policy, edited by E. Davis and F. Styles. Davis, Calif.: University of California Press, 1971.

Morrison, P., with J. Wheeler. "Rural Renaissance in America? The Revival of Population Growth in Remote Areas." Population Bulletin, vol. 31, 1976.

Norton, R., and J. Rees. "The Product-Cycle and the Spatial Decentralization of American Manufacturing." Regional Studies, 13(1979): 141-152.

Park, S., and J. Wheeler. "The Filtering Down Process in Georgia: The Third Stage in the Product Life Cycle." The Professional Geographer, 35(1983):18-31.

Parsons, J. "California Manufacturing." The Geographical Review, 39(1949):229-241.

Paschall, G. The Forces Shaping California's Economic Future. California Taxpayers' Association, 1977.

Peet, R. "Relations of Production and the Relocation of United States Manufacturing Industry since 1960." Economic Geography, 59(1983):112-143.

Rees, J. "Technological Change and Regional Shifts in American Manufacturing." The Professional Geographer, 31(1979):45-54.

Richardson, H., and P. Gordon. "Economic and Fiscal Impacts of Metropolitan Decentralization." Environment and Planning A, 11(1979):643-654.

Roepke, H., and D. Freudenberg. "The Employment Structures of Nonmetropolitan Counties." Annals, Association of American Geographers, 71(1981):580-592. 
Schwarzweller, H. “Migration and the Changing Rural Scene." Rural Sociology, 44(1979):7-23. Scott, A. The Urban Land Nexus and the State. London: Pion, 1980.

Scott, A. "Locational Patterns and the Dynamics of Industrial Activity in the Modern Metropolis: A Review Essay." Urban Studies, vol. 19, pp. 111-142, 1982a.

Scott, A. "Production System Dynamics and Metropolitan Development." Annals, Association of American Geographers, vol. 72, pp. 180-200, 1982b.

Slaughter, P. Industrial Deconcentration and the Population Turnaround. Unpub. Ph.D. dissertation, Washington State University, Pullman, 1980.

Sokolow, A. "California's New Migration to the Towns of the 'Cow Counties'" California Journal, 8(1977):348-350.

Sundquist, J. Dispersing Population: What America Can Learn from Europe. Washington, D.C.: The Brookings Institute, 1975.

Thompson, W. "The Economic Base of Urban Problems," in Contemporary Economic Issues, edited by N. Chamberlain. Chicago: Richard Irwin, 1973.

Till, T. "Industrialization and Poverty in Southern Nonmetropolitan Labor Markets." Growth and Change, 5(1974):18-24.

Tregarthen, T. "If Cities Are So Great, Why Are People Leaving?" Environment and Planning A, 9(1977): 1421-1422.

Tucker, C. "Changing Patterns of Migration Between Metropolitan and Nonmetropolitan Areas in the United States: Recent Evidence." Demography, 13(1976):435-443.

Vance, J. "California and the Search for the Ideal." Annals, Association of American Geographers, 62(1972): 185-210.

Walker, R., and M. Storper. "Capital and Industrial Location." Progress in Human Geography, $5(1981): 473-509$.

Wardwell, J. "Equilibrium and Change in Nonmetropolitan Growth." Rural Sociology, 42(1977):156-179.

Warner, W. "Rural Society in a Post-Industrial Age." Rural Sociology, 39(1974):306-318.

Webster, P. Population Movements in California, Non-urban Areas 1930-1935. Washington, D.C.: U.S. Department of Agriculture Resettlement Administration, 1937.

Zelinsky, W. "Coping with the Migration Turnaround: The Theoretical Challenge." International Regional Science Review, 2(1977):175-178. 